\title{
In Vitro Cultivated Uncaria tomentosa and Uncaria guianensis with Determination of the Pentacyclic Oxindole Alkaloid Contents and Profiles
}

\author{
Rita de C. A. Pereira, ${ }^{*}, a$ Ligia M. M. Valente, ${ }^{b}$ José E. B. P. Pinto, ${ }^{c}$ Suzan K. V. Bertolucci, ${ }^{c}$ \\ Giselle M. Bezerra, ${ }^{b}$ Flaviane F. Alves, ${ }^{b}$ Priscila F. P. dos Santos, ${ }^{b}$ Paulo J. C. Benevides, ${ }^{d}$ \\ Antônio C. Siani, ${ }^{d}$ Sandra L. Rosario, ${ }^{d}$ José L. Mazzei, ${ }^{e}$ Luiz A. d'Avila, ${ }^{e}$ Luiz N. F. Gomes, ${ }^{b}$ \\ Francisco R. de Aquino-Neto, ${ }^{b}$ Isabel C. M. Emmerick ${ }^{b}$ and Sergio F. Carvalhaes ${ }^{b}$ \\ ${ }^{a}$ Embrapa Agroindústria Tropical, Rua Dra. Sara Mesquita 2270, 60511-110, Fortaleza-CE, Brazil \\ ${ }^{\text {b}}$ Universidade Federal do Rio de Janeiro, Instituto de Química, C.T., Bloco A, 21941-909, Rio de Janeiro-RJ, Brazil \\ ${ }^{c}$ Universidade Federal de Lavras, Departamento de Agricultura, Campus Universitário, \\ CP 3037, 37200-000, Lavras-MG, Brazil \\ ${ }^{d}$ Fundação Oswaldo Cruz, Instituto de Tecnologia em Fármacos, R. Sizenando Nabuco 100, \\ 21041-250, Rio de Janeiro-RJ, Brazil
}

${ }^{e}$ Universidade Federal do Rio de Janeiro, Escola do Química, C.T., Bloco E, 21949-900, Rio de Janeiro-RJ, Brazil

\begin{abstract}
Uncaria tomentosa (Willd.) DC. e Uncaria guianensis (Aubl.) Gmel., conhecidas comercialmente como unha-de-gato, são trepadeiras lenhosas nativas das florestas tropicais amazônica e centralamericana. Essas espécies de Rubiaceae enfrentam ultimamente um eminente risco de extinção devido tanto ao extrativismo indiscriminado quanto ao desflorestamento de seus habitats naturais. Esse trabalho descreve métodos de cultivo in vitro para as duas espécies, analisando o perfil e o teor dos alcalóides oxindólicos pentacíclicos marcadores por CLAE no material vegetal obtido. Os resultados mostraram que os métodos desenvolvidos foram capazes de produzir plantas com perfil e teor dos alcalóides alvos similares à plantas nativas e cultivadas in vivo, com a vantagem adicional de produção em menor tempo de mudas próprias para plantio no campo. Os dados evidenciaram que o cultivo in vitro pode ser uma ferramenta viável para a produção das duas espécies com impacto na sua comercialização e na preservação das florestas.
\end{abstract}

Uncaria tomentosa (Willd.) DC. and Uncaria guianensis (Aubl.) Gmel., commercially known as cat's claw, are large woody vines native of the Amazon and Central America rainforests. These Rubiaceae species face nowadays an imminent risk of extinction due to indiscriminate harvesting in the wild as well as to increasing deforestation of their natural habitat. This work describes in vitro cultivation methods for both species with determination, by HPLC, of the pentacyclic oxindole alkaloid contents and profiles of the plant material. The results have proved that the methods we developed were able to produce plants with alkaloid profiles and contents similar to the wild and in vivo cultivated species, and with the additional advantage of producing suitable young plants in a shorter period of time. The data showed that the in vitro technique can be a feasible tool for the growth of the species, and may thus be important for their commercialization and for their conservation as a forest resource.

Keywords: Uncaria tomentosa, Uncaria guianensis, cat's claw, micropropagation, oxindole alkaloids

\section{Introduction}

The species Uncaria tomentosa (Willd.) DC. and Uncaria guianensis (Aubl.) Gmel. (Rubiaceae) known

*e-mail: cassia@cnpat.embrapa.br as cat's claw are large woody vines native of the Amazon rainforest and other tropical areas of South and Central America. ${ }^{1}$ They have been used in traditional medicine practically in largely similar ways to treat several ills such as gastritis, gastric ulcers, cancer, arthritis, asthma and inflammatory conditions. ${ }^{2-4}$ The species $U$. guianensis 
showed experimentally anti-inflammatory and anti-oxidant activities and $U$. tomentosa is noted for its immunostimulant activity, as well as cytotoxic, anti-inflammatory and antioxidant action. ${ }^{5-7}$. The bioactivities of the species have made them valuable plant materials and led to them being commercialized in natura or as phytopharmaceutical derivatives. ${ }^{8}$ Both species contain, in different proportions, tetra- and pentacyclic oxindole alkaloids, indole alkaloids, triterpenoid glycosides, sterols and flavonoids. ${ }^{6}$ In vitro and in vivo assays have demonstrated that the pentacyclic oxindole alkaloids (POA) were the main source of the immunostimulant and cytotoxic activity of $U$. tomentos $a^{6,9}$ and led to them being considered biochemical markers of this species and been used to assure the quality of the plant material and commercial herbal medicines. ${ }^{10-13}$ The concentration of these alkaloids varies in the different parts of the plants as well as seasonally and they are usually more abundant in $U$. tomentosa than in $U$. guianensis. ${ }^{14,15}$ The species face nowadays an imminent risk of extinction due to indiscriminate harvesting in the wild as well as to increasing deforestation of their natural habitat. ${ }^{3,16}$ The medicinally used parts are root bark, stem bark and leaves harvested from specimens with an age of $c a$. 8-10 years..$^{3,17}$ In order to minimize the impact of the extractivism and look for sustainable use of the species some cultivation initiatives have been made from seeds and/or from root or stem stocks and also by developing ideal harvesting techniques that allow a quicker regrowth. ${ }^{4,18-20}$ Still poorly explored, cell culture methods could become a useful tool for propagation of the species as well as for the production of the bioactive oxindole alkaloids. Three studies have reported the development of cell suspension culture methods from leaf explants of $U$.tomentosa aimed at the production of oxindole alkaloids ${ }^{17,21,22}$ and another experiment has described cell culture conditions to study the biosynthetic pathways of sterols and triterpenes in $U$. tomentosa. $^{23}$
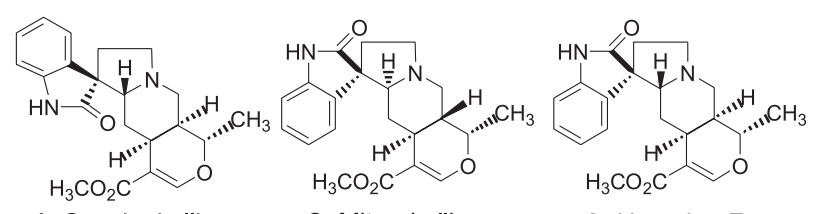

1- Speciophylline
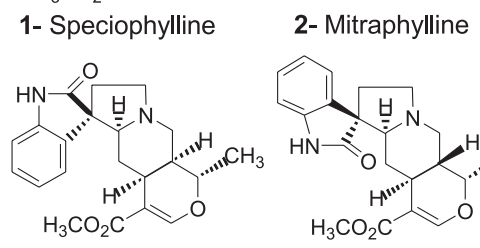

4- Pteropodine

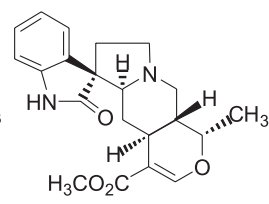

3- Uncarine $\mathrm{F}$

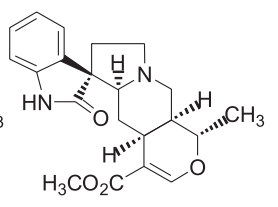

5- Isomitraphylline

6- Isopteropodine

Figure 1. Structures of the pentacyclic oxindole alkaloids regarded as biochemical markers of Uncaria tomentosa and Uncaria guianensis.
The present investigation describes the POA 1-6 (Figure 1) profiles and their total content through HPLC in micropropagated $U$. tomentosa and $U$. guianensis species. The study seeks to obtain in vitro cultivated Uncaria species with similar POA profile and content to the wild species in order to contribute to their commercial use and to their conservation as a forest resource.

\section{Experimental}

\section{Plant matrices}

The seeds utilized to obtain the plant matrices were obtained from Embrapa Acre, Brazil, collected from wild adult specimens in the Brazilian Amazon rainforest in Boca do Acre, Amazonas (Uncaria guianensis) and Feijó, Acre (Uncaria tomentosa) in August 2003. Voucher species are deposited at the Herbarium of the Zoobotanic Park of the Universidade Federal do Acre (Brazil) under numbers 15640 and 15645, respectively. The seeds of both species were washed in tap water for $10 \mathrm{~min}$ and then disinfected in a laminar flow chamber with a $1.25 \%$ aqueous solution of sodium hypochlorite for $15 \mathrm{~min}$. After that the seeds were exhaustively washed with autoclaved distilled water for removal of the excess of the disinfectant solution. The aseptic seeds were then germinated during 60 days in a greenhouse using Plantmax ${ }^{\circledR}$ substrate and then transplanted into $4 \mathrm{~kg}$ plastic bags with the same substrate and kept under $50 \%$ shade and intermittent sprinkling irrigation. After six months the seedlings could be transferred to the field. Leaves (median part of the shoot and anatomic structures fully developed) from these seed cultivated specimens at 24 months were used for the alkaloid determination.

\section{Calli from in vitro leaf explants}

Leaf segments of $1 \mathrm{~cm}^{2}$ were taken from the plant matrices and were inoculated in flasks with $10 \mathrm{~mL}$ of Murashige and Skoog (MS) medium ${ }^{24}$ containing $1.5 \mathrm{mg} \mathrm{L}^{-1}$ of 4-amino-3,5,6-trichloropicolinic acid (Picloram), inorganic salts, inositol, vitamins, $6 \mathrm{~g} \mathrm{~L}^{-1}$ of agar and $30 \mathrm{~g} \mathrm{~L}^{-1}$ of sucrose. After 60 days of continued cultivation, the calli were successively sub-cultivated four times in the same medium. For phytochemical analyses dry calli (ventilated oven at $45^{\circ} \mathrm{C}$ ) with 30,60 and 90 days after the fourth sub-cultivation were used.

\section{In vitro plantlets}

Aseptic seeds of $U$. guianensis obtained as described above and leaf explants of $U$. tomentosa plant matrix 
were used for the in vitro inoculation. The embryos of $U$. guianensis and the leaf explants from $U$. tomentosa were inoculated in a laminar flow chamber in $25 \times 150 \mathrm{~mm}$ test tubes with, for $U$. guianensis, $10 \mathrm{~mL}$ of the complete MS culture medium supplemented with $30 \mathrm{~g} \mathrm{~L}^{-1}$ of sucrose, $6.0 \mathrm{~g} \mathrm{~L}^{-1}$ of agar and $\mathrm{pH} 5.7$ and, for U. tomentosa, $10 \mathrm{~mL}$ of the WPM medium ${ }^{24}$ supplemented with $1.0 \mathrm{mg} \mathrm{L}^{-1}$ of 6-benzylaminopurine (BAP) and then incubated at $25 \pm 1^{\circ} \mathrm{C}$ with a $16 \mathrm{~h}$ photoperiod $\left(15 \mu \mathrm{mol}\left(\mathrm{m}^{2} \mathrm{~s}\right)^{-1}\right)$. After 45 days the plantlets of both species were removed from the test tubes and their leaves were excised and dried in a ventilated oven at $30{ }^{\circ} \mathrm{C}$ and then submitted to alkaloid analysis. Leaves from three different plantlets of each species were used for the alkaloid determination.

\section{Acclimatization of the in vitro plantlets}

After 45 days the in vitro produced plantlets (described above) were transferred to a 72 cell tray with $50 \mathrm{~mL} \mathrm{cell}^{-1}$ of Plantmax ${ }^{\circledR}$ substrate and after 15 days the seedlings were transplanted to $1 \mathrm{~kg}$ plastic pots and kept in a greenhouse at the same conditions described for the production of the plant matrices. For alkaloid determination leaves from three different specimens of both species were collected on the $30^{\text {th }}$ and $45^{\text {th }}$ day of the acclimatization and dried in a ventilated oven at $30^{\circ} \mathrm{C}$.

\section{Extraction and quantification of the alkaloids}

A mass of $750 \mathrm{mg}$ of the oven-dried and powdered in vitro and in vivo cultivated plant material from both species were ultrasonically extracted with HPLC grade $\mathrm{MeOH}(4 \times 2.5 \mathrm{~mL})$ according to the Ganzera et al. ${ }^{12}$ optimized method. The extractions were made in triplicate. The extracts were filtered, the solvents evaporated under low pressure at $37{ }^{\circ} \mathrm{C}$ and the residues weighed. Solutions ca. $5 \mathrm{mg} \mathrm{L}^{-1}$ were then made with each one by adding the appropriate amount of $\mathrm{MeOH}$. These solutions were added to the macroporous cationic resin Lewatit SP-112 (Bayer) (1:4 extract-mg/resin-mg) and stirred magnetically for $1 \mathrm{~h}$ for the retention of the alkaloids. ${ }^{25}$ The supernatants were then carefully separated and the resin washed with $\mathrm{MeOH}$ $(2 \times 5 \mathrm{~mL})$ followed by stirring with $\mathrm{MeOH} / \mathrm{NH}_{4} \mathrm{OH} 1: 1$ $(3 \times 5 \mathrm{~mL})$ for $5 \mathrm{~min}$. The alkaloid-rich supernatants were filtered and the solvents evaporated under low pressure at $37{ }^{\circ} \mathrm{C}$. The resulting fractions were weighed and quantitatively transferred to volumetric flasks with $\mathrm{MeOH}$ to yield solutions with concentrations varying from 300 to $700 \mu \mathrm{g} \mathrm{mL}^{-1}$. These solutions were filtered through $0.45 \mu \mathrm{m}$ nylon membranes and injected $(10 \mu \mathrm{L})$ in triplicate into the HPLC system (500E Waters with automatic injector and photodiode array detector HP series 1100 , connected to a HP Asterix Chemstation) equipped with a reverse-phase $\mathrm{C}_{18}$ column (Lichrocart Lichrospher $5 \mu \mathrm{m}, 125 \times 4.6 \mathrm{~mm}$ i.d.). Elution was carried out with a mixture of $45 \%$ of $\mathrm{MeCN} / 55 \%$ of aqueous $30 \mathrm{mmol} \mathrm{L}^{-1} \mathrm{NH}_{4} \mathrm{OAc}$ solution, $\mathrm{pH}$ adjusted at 6.8-7.0, isocratic mode, flow rate of $1.0 \mathrm{~mL} \mathrm{~min}^{-1}$, at $60^{\circ} \mathrm{C}$ and detection at $245 \mathrm{~nm} .{ }^{26}$ The alkaloids peaks were identified by retention time relative to isopteropodine $(\mathbf{6})$ in an authenticated POA reference sample described below. Amounts of each POA in the extracts were quantified by external standardization relative to isopteropodine (6). This external calibration curve was prepared from injections in triplicate of isopteropodine $\mathrm{MeOH}$ solutions at five different concentrations and it presented suitable linearity $\left(\mathrm{R}^{2}=0.994\right)$ in the range of 3.12 to $25.0 \mu \mathrm{g} \mathrm{mL}^{-1}$. The detectable minimum was determined as $2.4 \mu \mathrm{g} \mathrm{mL}^{-1}$ in the calibration curve and the standard deviation was estimated as $1.0 \mu \mathrm{g} \mathrm{mL} \mathrm{m}^{-1}$.

\section{Reference sample}

In order to identify each alkaloid peak in the HPLC chromatograms a reference sample was used. This sample is an enriched fraction that contains the six POA obtained through classical acid-base partition ${ }^{27}$ from the EtOH$\mathrm{H}_{2} \mathrm{O} 1: 1$ extract of the stem bark of a wild specimen of U. tomentosa collected in Cruzeiro do Sul, Acre, Brazil [donated by Biosapiens Co., Brazil - for voucher data see Miranda et al. $\left.{ }^{19}\right]$. This fraction was submitted to reversephase HPLC using UV-detector at $245 \mathrm{~nm}$ under the same conditions described by Laus and Keplinger ${ }^{11}$ with the identification of the POA signals made by comparison of their retention times with those described ${ }^{27}$ and also by HPLC-DAD-MS analysis ${ }^{28}$ by monitoring the ion $[\mathrm{M}+1]^{+}$ at $m / z, 369$ and the corresponding UV spectra. ${ }^{26}$ In order to obtain the pure standard compounds, this fraction was suspended in boiling methyl tert-butyl ether to precipitate mitraphylline (2) that was further purified by crystallization in the same solvent. After evaporation of the solvent at low pressure at $37{ }^{\circ} \mathrm{C}$, the supernatant was sequentially submitted to silica gel column chromatography using a solvent gradient of hexane-EtOAc-MeOH and reverse-phase HPLC. ${ }^{11,29}$ The obtained pure compounds were analyzed by ${ }^{1} \mathrm{H}$ and ${ }^{13} \mathrm{C}$ NMR in one and two dimensions (Bruker DRX-300 spectrometer operating at $300 \mathrm{MHz}$ and using $\mathrm{CDCl}_{3}$ as solvent and TMS as internal reference), FTIR (Nicolet model Magna-IR 760 spectrometer) and HPLCDAD-MS (2690 Waters chromatography with photodiode array detector Waters 996 model and quadripole micromass ZMD mass spectrometer with electrospray interface) and their data compared with those available in the literature. ${ }^{28,30}$ 
The purity of the isolated compounds was determinated by integration of the total ion chromatogram in the HPLC-MS. The compounds were obtained with more than $95 \%$ purity. Individual compounds were then injected and the retention times relative to isopteropodine (6) were determinated: speciophylline (1) 0.39 , mitraphylline (2) 0.45 , uncarine F (3) 0.48, pteropodine (4) 0.59, isomitraphylline (5) 0.62 and isopteropodine (6) 1.00 .

\section{Results and Discussion}

Several methods for characterization and quantification of the POA from Uncaria tomentosa and Uncaria guianensis have been reported 10-12,28,31. Because of the complexity of the crude alcoholic extracts of both species which contain a large amount of tannins, the oxindole alkaloids have usually been analyzed with a pre-treatment of those extracts with acidic or basic extraction, acid-base partition or solid phase extraction in order to achieve alkaloid-enriched fractions. The present study reports the obtaining of the alkaloid fractions from the developed cultivars by using a solid phase extraction methodology based on cationic exchange. ${ }^{25}$ For analytical purposes and as an alternative to the alkaloid standards, a noncommercial reference sample containing the POA 1-6, obtained by classical acid-base partition from an ethanol extract of the stem bark of a Brazilian wild specimen of U. tomentosa, was chemically authenticated. This authentication involved the isolation of the six POA standard compounds whose structures have been confirmed by FT-IR, NMR techniques and HPLC-DAD-MS. Characterization of the six marker compounds in all analyzed samples was related to their relative retention time to isopteropodine (6). Amounts of each POA in the extracts were quantified by external standardization relative to isopteropodine (6). The alkaloid profile of the reference sample is shown at Figure 2.

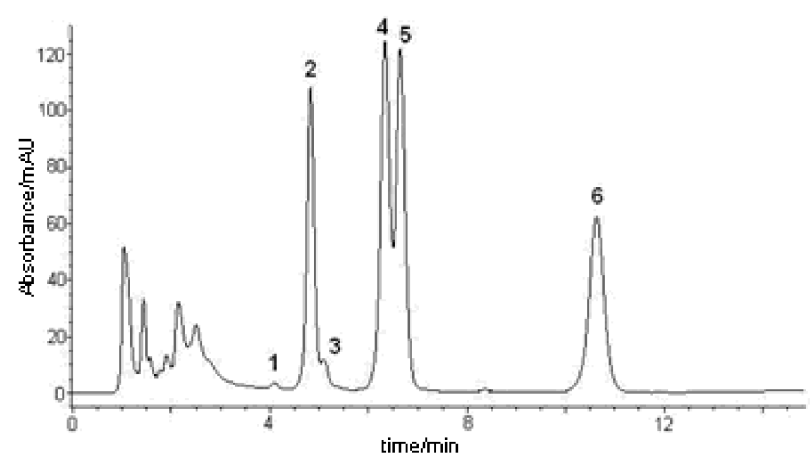

Figure 2. Pentacyclic oxindole alkaloid HPLC profile of the reference sample: 1: Speciophylline; 2: Mitraphylline; 3: Uncarine F; 4: Pteropodine; 5: Isomitraphylline; 6: Isopteropodine.
Plant matrices of both species were produced from seeds. This allowed comparison of the time of development of the seedlings and their alkaloid profiles with plants produced by in vitro propagation. These matrices were also used to take leaf explants to obtain plantlets of $U$. tomentosa and calli of both species. It is already known that the species can be produced by seed germination ${ }^{32,33}$ and in the present study both species germinated completely within 60 days and were then maintained for six months in pots in a greenhouse, before transfer of the young plants to the field. After 24 months leaf samples were harvested and submitted to alkaloid analysis. The alkaloid profile of $U$. tomentosa plant matrix is shown in Figure 3(a) and that of $U$. guianensis in Figure 4(e). The total amount of alkaloid in the U. tomentosa leaf matrix (19.8 $\left.\mathrm{mg} \mathrm{g}^{-1}\right)$ was around four-fold higher than in the $U$. guianensis leaf matrix $\left(4.43 \mathrm{mg} \mathrm{g}^{-1}\right)$ (Table 1$)$. The higher content of alkaloid in $U$. tomentosa corresponds to the data already described for seed or stem stock cultivated Peruvian plants. ${ }^{14,15}$ A low concentration of speciophylline (1) and the absence of uncarine F (3) was observed in both matrices, quite similar to the POA profile of the reference sample obtained from a wild Brazilian U. tomentosa specimen (Figure 2, 3(a) and 4(e), Table 1).

Although seeds can be used to propagate these Uncaria species, generally, it can be difficult because viability rapidly declines after dehiscing, ${ }^{20,34}$ collection in the wild is not easy since flowering occurs normally only once a year and the species themselves are frequently located in areas of difficult access. ${ }^{18,19}$ In addition a significant seasonal variation of the alkaloid profile and content in several parts of seed or stem stock cultivated specimens of both species was reported. ${ }^{14,15}$ Thus, empirical examinations of in vitro cultivation methods for both Uncaria species were carried out in order to obtain rapid multiplication of those cultivars with morphologically homogeneous plants with desirable POA profiles and contents. Various techniques for the in vitro propagation of woody species are available and they can provide several identical individuals with economy of time and space. ${ }^{35}$

Callus inductions were obtained using previously developed optimized conditions that took into account the callus maximal growth rate. ${ }^{36,37}$ In the search for these conditions the influence of four auxins [indolebutyric acid (IBA), 1-naphthylacetic acid (NAA), 2,4-dichlorophenoxyacetic acid (2,4-D) and 4-amino3,5,6-trichloropicolinic acid (Picloram)] at different concentrations were evaluated for both species in MS culture medium with $0.6 \%$ of agar and $3 \%$ of sucrose. The results showed that with Picloram supplement at $0.5 \mathrm{mg} \mathrm{L}^{-1}$ the best callus inductions and maximal growth rate for both species were obtained. NAA was unable to promote 

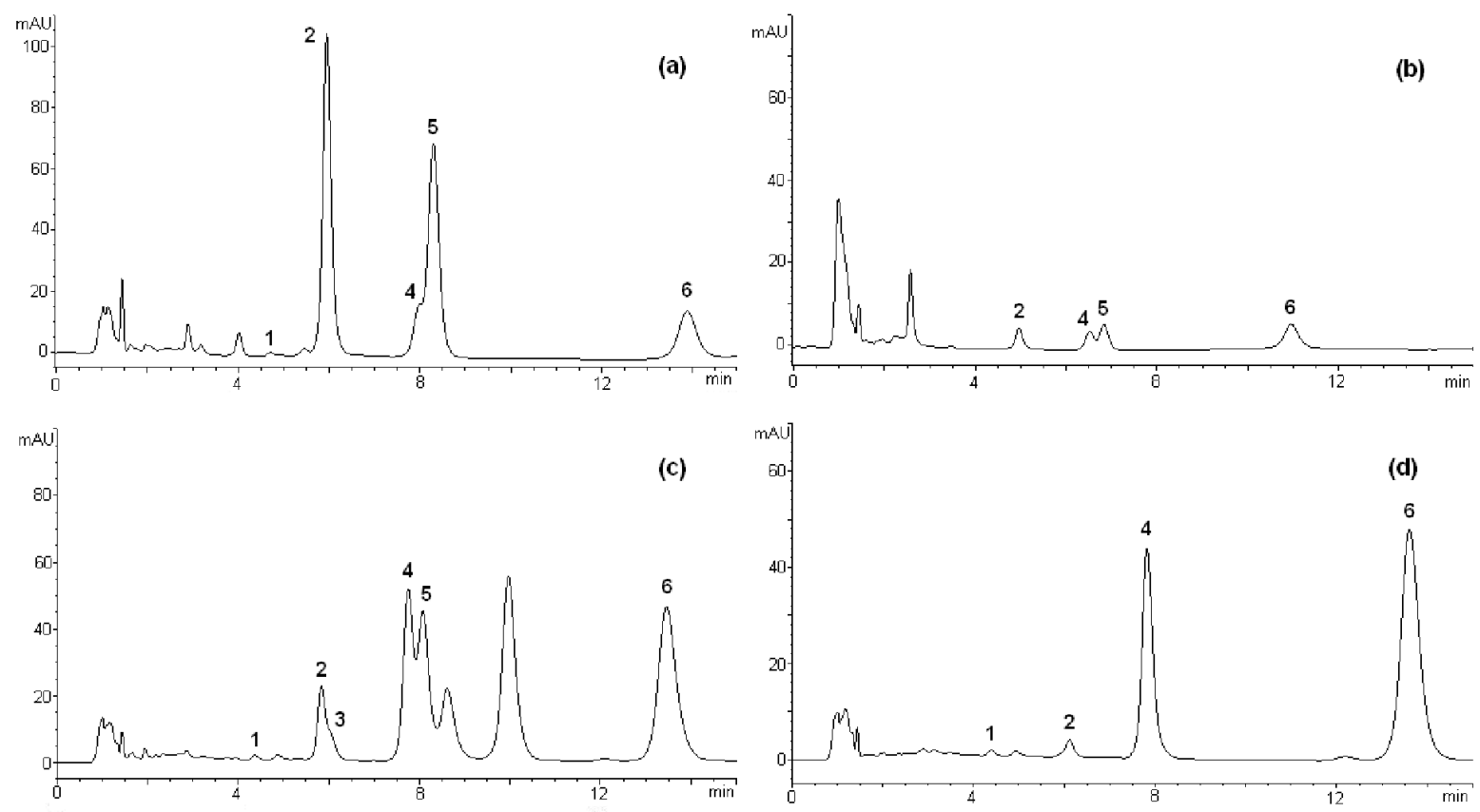

Figure 3. Pentacyclic oxindole alkaloid HPLC profiles of the U. tomentosa (UT) samples: 1: Speciophylline; 2: Mitraphylline; 3: Uncarine F; 4: Pteropodine; 5: Isomitraphylline; 6: Isopteropodine. (a) UT leaf matrix; (b) UT plantlets; (c) UT plantlets acclimatized for 30 days; (d) UT plantlets acclimatized for 45 days.
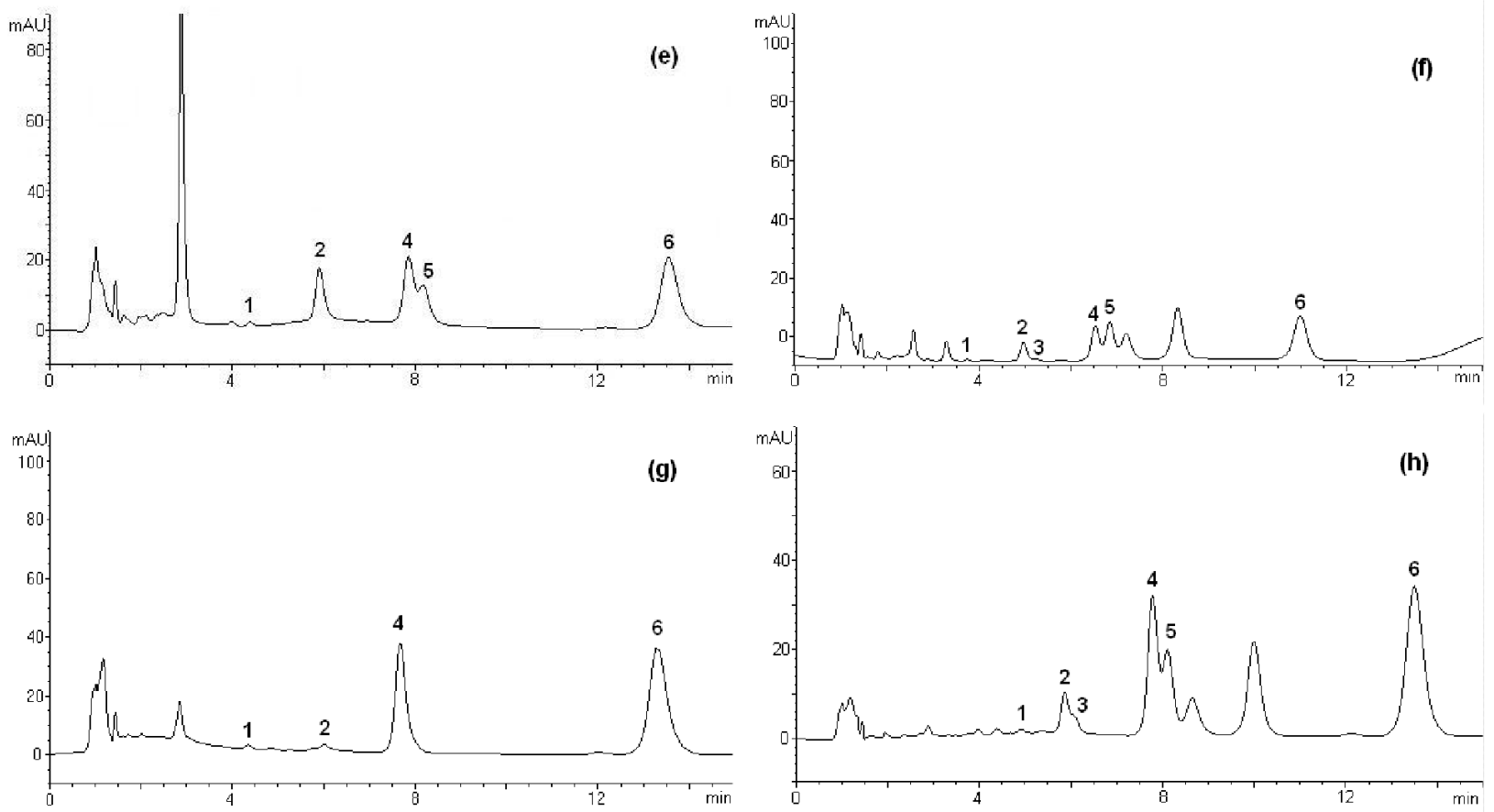

Figure 4. Pentacyclic oxindole alkaloid HPLC profiles of the U. guianensis (UG) samples: 1: Speciophylline; 2: Mitraphylline; 3: Uncarine F; 4: Pteropodine; 5: Isomitraphylline; 6: Isopteropodine. (e) UG leaf matrix; (f) UG plantlets; (g) UG plantlets acclimatized for 30 days; (h) UG plantlets acclimatized for 45 days.

induction in both species, 2,4-D promoted induction only in $U$. guianensis and IBA barely promoted a weak induction in $U$. guianensis. After the callus induction protocols for both species had been defined, fresh sets of the material were prepared and those cultivated for 30,60 and 90 days were submitted to POA analyses. The results revealed no target alkaloids in the analyzed calli showing that the callus development conditions in spite of the good biomass 
Table 1. Total alkaloid content and percentage of distribution of the pentacyclic oxindole alkaloids on the plant matrices, plantlets and acclimatized plantlets methanol extracts of Uncaria tomentosa and Uncaria guianensis

\begin{tabular}{|c|c|c|c|c|c|c|c|c|c|}
\hline & \multirow{2}{*}{ Samples } & \multirow{2}{*}{ Total alkaloids ${ }^{\mathrm{a}} /(\mathrm{mg} / \mathrm{g} \pm 3 \%)$} & \multicolumn{6}{|c|}{ Percentage of distribution of $\mathrm{POA}^{\mathrm{b}}$} & \multirow{2}{*}{ Total percentage of $\mathrm{POA}^{\mathrm{b}}$} \\
\hline & & & 1 & 2 & 3 & 4 & 5 & 6 & \\
\hline \multirow{4}{*}{ U. tomentosa } & (a) & 19.8 & 0.46 & 26.6 & - & 4.02 & 17.3 & 12.6 & 61.0 \\
\hline & (b) & 2.00 & - & 5.58 & - & 5.07 & 9.75 & 17.4 & 37.8 \\
\hline & (c) & 16.3 & 0.48 & 6.11 & 0.50 & 14.1 & 13.7 & 23.3 & 58.2 \\
\hline & (d) & 23.3 & 0.76 & 2.45 & - & 27.3 & - & 52.6 & 83.1 \\
\hline \multirow{4}{*}{ U. guianensis } & (e) & 4.43 & 0.41 & 6.92 & - & 11.2 & 6.57 & 20.4 & 45.5 \\
\hline & (f) & 2.00 & 0.65 & 3.93 & 0.43 & 8.63 & 10.9 & 18.1 & 42.6 \\
\hline & (g) & 8.30 & 0.27 & 1.49 & - & 21.3 & - & 34.3 & 57.4 \\
\hline & (h) & 12.3 & 0.45 & 5.15 & 0.49 & 16.9 & 10.6 & 33.0 & 66.6 \\
\hline
\end{tabular}

a $n=3$; ${ }^{\mathrm{b}}$ In area percent; POA: Pentacyclic Oxindole Alkaloids; (a) and (e): plant matrices; (b) and (f): plantlets; (c) and (g): plantlets acclimatized for 30 days; (d) and (h): plantlets acclimatized for 45 days; 1: Speciophylline; 2: Mitraphylline; 3: Uncarine F; 4: Pteropodine; 5: Isomitraphylline; 6: Isopteropodine.

production were still inappropriate for POA production. The influence of the auxins 2,4-D and indole-3-acetic acid (IAA) and sucrose concentration (supplemented with kinetin in MS culture medium) has been recently demonstrated in the production of the POA mitraphylline (2), pteropodine (4) and isopteropodine (6) by $U$. tomentosa cell suspension cultures. ${ }^{17}$ The biosynthetic production of the POA seems to originate from the related indole alkaloids and both alkaloid types can occur together in $U$. tomentosa and $U$. guianensis..$^{14,15}$ The influence of auxins and the culture medium on the production of indole alkaloids in callus culture of $U$. rhynchophylla has been described ${ }^{38}$ and clearly showed that callus induction and growth and alkaloid production were dissociated in some conditions. The conditions used in this study for obtaining calli of $U$. guianensis and $U$. tomentosa, although they produced non-satisfactory callus culture for POA production, did emphasize the different behaviors of the two plant species studied. Some other differences related to alkaloid contents and pharmacological activities have been mentioned by authors such as Laus and Kepligler ${ }^{15}$ and Sandoval et al., ${ }^{39}$ leading to an interesting discussion about their similar use in folk medicine.

As an alternative, the species were micropropagated by developing plantlets of both species using conditions previously optimized for a high percentage of germination and maximal growth. The search for these optimized conditions was made by empirical variation of different factors such as culture medium, sucrose concentration, explant inoculation position, etc. ${ }^{37,40}$ In this previous work it was pointed out that while embryos of $U$. guianensis were excellent sources for micropropagation purposes, for $U$. tomentosa their use under several different conditions did not lead to in vitro germination. On the other hand, leaf explants of $U$. tomentosa have been successfully used. Thus, after the in vitro propagation protocols for both species had been defined, fresh sets of plantlets were produced in order to analyze their POA profiles. The plantlets obtained from both species in the optimized conditions showed the same alkaloid contents (2.00 $\mathrm{mg} \mathrm{g}^{-1}$, Table 1) but some differences in the POA profiles. They showed a low concentration of speciophylline (1) and absence or a low concentration of uncarine F (3) like the plant matrix POA profiles and predominance of isopteropodine (6) (Figure 3(b) and 4(f), Table 1). The total percentage (area percent) of POA in $U$. tomentosa plantlets was $37.8 \%$ while in $U$. guianensis plantlets it was $42.6 \%$ (Table 1). In addition the $U$. guianensis plantlet alkaloid profile showed non-identified alkaloids with a retention time between isomitraphylline (5) and isopteropodine (6) (Figure 4(f)). Subsequently the plantlets were acclimatized in a greenhouse in the same conditions of the plant matrices in order to accompany their behavior ${ }^{37,41}$ as well as to analyze possible changes in their POA profiles. Leaves from both species at two points of the acclimatization period showed a remarkable improvement in the total alkaloid content, especially for $U$. tomentosa (Table 1), as well as interesting alkaloid profiles. The total alkaloid amounts found in the leaves of plantlets of $U$. tomentosa acclimatized for 30 and 45 days were 16.3 and $23.3 \mathrm{mg} \mathrm{g}^{-1}$ respectively which is quite similar to the amount found for the $U$. tomentosa leaf matrix $(19.8 \mathrm{mg}$ $\left.\mathrm{g}^{-1}\right)$. However for $U$. guianensis the amounts found were significantly higher than the amount found for its matrix (4.43 $\left.\mathrm{mg} \mathrm{g}^{-1}\right): 8.30 \mathrm{mg} \mathrm{g}^{-1}$ for 30 days of acclimatization and $12.3 \mathrm{mg} \mathrm{g}^{-1}$ for 45 days of acclimatization (Table 1). The chromatograms revealed for $U$. tomentosa leaves collected on the 30th day of acclimatization the presence of the six POA markers together with the non-identified alkaloids with retention times between isomitraphylline (5) and isopteropodine (6) (Figure 3(c)) and for the leaves collected 15 days later five POA with predominance of 
pteropodine (4) and isopteropodine (6) (Figure 3(d), Table 1). However for $U$. guianensis the leaves collected at the 30th day of acclimatization showed four POA with the predominance of pteropodine (4) and isopteropodine (6) (Figure 4(g), Table 1) and those collected 15 days later all six oxindole alkaloid markers together with the non-identified alkaloids with retention times between isomitraphylline (5) and isopteropodine (6) (Figure 4(h)). Laus et al. ${ }^{14}$ have reported for the seasonal screening of indole and oxindole alkaloids in several parts of seed or root stock of cultivated Peruvian species of $U$. tomentosa collected in different locations, a higher content of alkaloids in young leaves than in mature leaves and a significant seasonal variation of the alkaloid content. For cultivated and wild Peruvian species of $U$. guianensis ${ }^{15}$ the comparison of the alkaloid content between young and mature leaves did not show a significant variability, but was limited to mitraphylline (2) and isomitraphylline (5) as the only POA in all samples. All these previous results, added to those found for our plant materials, confirm the complexity and variability of POA profiles for in vivo and in vitro cultivated specimens of both studied species. Since seed germination presents the inconveniences already mentioned and a germination time that may vary depending on the region in which the plant is growing, and that stem stock germination, due to the high humidity ${ }^{20,34}$ it requires, also presents some limitations, our results show the feasibility of the in vitro propagation methodology for a quicker and controlled cultivation of $U$. tomentosa and $U$. guianensis, producing suitable young plants to be transferred to the field in a shorter period of time with no limitation of season or scale. This is, to the best of our knowledge, the first report of plantlet propagation protocols for the South-American species of Uncaria with the additional characterization and quantification of their POA. They also provide data on alkaloid composition of Brazilian Uncaria species which are currently scanty. The unidentified compounds produced in same micropropagated samples will be further accomplished. These results proved that micropropagation is a feasible tool for the growth of the species, and may thus be important for their commercialization and for their conservation as a forest resource.

\section{Acknowledgments}

The authors thank CNPq-Brazil for grant support. J.E.B.P.P., A.C.S., F.F.A., P.F.P.S. and F.R.A.N. thank CNPq; S.L.R. and G.M.B thank FAPERJ-Brazil and J.L.M. thanks CAPES-Brazil for fellowship support. The authors also thank Dr. B. Gilbert for his kind assistance on the manuscript revision.

\section{References}

1. Ridsdale, C. E.; Blumea 1978, 24, 43.

2. Revilla, J.; Plantas Úteis da Bacia Amazônica; Instituto Nacional de Pesquisas da Amazônia/SEBRAE-AM: Manaus, 2002.

3. Jones, K.; Cat's Claw, Healing Vine of Peru; Sylvan Press: Seattle, 1995.

4. Obregón-Vilches, L.; Uña de Gato. Género Uncaria. Estudios Botánicos, Químicos y Farmacológicos de Uncaria tomentosa y Uncaria guianensis; Instituto de Fitoterapia Americano: Lima, 1997.

5. Gonçalves, C.; Dinis, T.; Batista, M. T.; Phytochemistry 2005, $66,89$.

6. Heitzmam, M. E.; Neto, C. C.; Winiarz, E.; Vaisberg, A.J.; Hammond, G. B.; Phytochemistry 2005, 66, 5.

7. Carvalho, M. V.; Penido, C.; Siani, A. C.; Valente, L. M. M.; Henriques, M. G. M. O.; Inflammopharmacology 2006, 14, 48.

8. Valente, L. M. M.; Rev. Fitos 2006, 2, 48.

9. Winkler, C.; Wirleitner, B.; Schroecksnadel, K.; Schennach, H.; Mur, E.; Fuchs, D.; Planta Med. 2004, 70, 205.

10. Stuppner, H.; Sturm, S.; Konwalinka, G.; Chromatographia 1992, 34, 597.

11. Laus, G.; Keplinger, D.; J. Chromatogr. 1994, 662, 243.

12. Ganzera, M.; Muhammad, I.; Khan, R. A.; Khan, I. A.; Planta Med. 2001, 67, 447.

13. Valente, L. M. M.; Alves, F. F.; Bezerra, G. M.; Almeida, M. B. S.; Rosario, S. L.; Mazzei, J. L.; d'Avila, L. A.; Siani, A. C.; Braz. J. Pharmacogn. 2006, 16, 216.

14. Laus, G.; Brossner, D.; Keplinger, K.; Phytochemistry 1997, 45,855

15. Laus, G.; Keplinger, K.; Phyton 2003, 43, 1.

16. Pollito, P. A. Z.; PhD Thesis, Escola Superior de Agricultura Luiz de Queiroz, Universidade de São Paulo, Brazil, 2004.

17. Luna-Palencia, G. R.; Cerda-Garcia-Rojas, C. M.; RodriguezMonroy, M.; Ramos-Valdivia, A.C.; Biotech. Prog. 2005, 21, 198.

18. Quiroz, J. D. Z.; Paucar, O. L.; García, W. R.; Nuevos Aspectos en el Estudio Agronómico y Fitoquimico de las dos Especies Peruanas del Género Uncaria: Uncaria tomentosa (Willd) DC. y la Uncaria guianensis (Aubl.) Gmel. "Uña de Gato". INMETRA; Lima: Peru, 2001.

19. Miranda, E. M.; Sousa, J. A.; Pereira, R. C. A.; Rev. Bras. Pl. Med. 2003, 5, 41.

20. Rocha, S. F. R.; Scarda, F. M.; Souza, N. N.; Silva, A. F. C.; Martins, F. S.; Ferreira, G. S.; Ferreira, C. F. A.; Ramos, F. M.; Pereira, R. O.; Moreira, L. F.; Rev. Bras. Pl. Med. 2004, 6, 28.

21. Trejo-Tapia, G.; Cerda-Garcia-Rojas, C. M.; RodriguezMonroy, M.; Ramos-Valdivia, A. C.; Biotech. Prog. 2005, 21, 786. 
22. Trejo-Tapia, G.; Sepulveda-Jimenez, G.; Trejo-Espino, J. L.; Cerda-Garcia-Rojas, C. M.; de la Torre, M.; Rodriguez-Monroy, M.; Ramos-Valdivia, A. C.; Biotechnol. Bioeng. 2007, 98, 230.

23. Flores-Sanchez, I. J.; Ortega-Lopez, J.; Montes-Horcasitas, M. D.; Ramos-Valdivia, A. C.; Plant Cell Physiol. 2002, 43, 1502.

24. Lloyd, G.; Mc Cown, B.; International Plant Propagators' Society Combined Proceedings of Annual Meeting, Washington, 1980.

25. Carvalhaes, S. F.; Costa, D. L.; Mazzei, J. L.; Taddei, L. E. M.; d'Avila, L. A.; Braz. J. Pharmacogn. 2002, 12, Supl., 83.

26. Mazzei, J. L.; PhD Thesis, Universidade Federal do Rio de Janeiro, Brazil, 2004.

27. Reis, S. R. I. N.; Valente, L. M. M.; Sampaio, A. L.; Siani, A. C.; Gandinia, M.; Azeredo, E. L.; d'Avila, L. A.; Mazzei, J. L.; Henriques, M. G. M. H.; Kubelka, C. F.; Int. Immunopharmacol. 2008, 8, 468.

28. Lopez-Avila, V.; Benedicto, J.; Robaugh, D.; J. High Resol. Chromatogr. 1997, 20, 231.

29. Mazzei, J. L.; Rosario, S. L.; Silva, R.S.; Siani, A. C.; Valente, L. M. M.; d'Avila, L. A.; Rev. Fitoterapia 2002, 2, 289.

30. Seki, H.; Takayama, H.; Aimi, N.; Sakai, S.; Ponglux, D.; Chem. Pharm. Bull. 1993, 41, 2077.

31. Montoro, P.; Carbone, V.; Quiroz, J. D.; De Simone, F.; Pizza, C.; Phytochem. Anal. 2004, 15, 55.
32. Revilla, J.; Plantas da Amazônia, Oportunidades Econômicas e Sustentáveis; SEBRAE-AM/INPA; Manaus: Brazil, 2001.

33. Torrejón, G. D.; Uña de Gato y Produccion Sostenible; Universidad Nacional Agraria La Molina, Lima: Peru, 1997.

34. Hughes, K.; Worth, T.; Cat's Claw or Uña de Gato an Overview. http://www.sunrisewd.com/products/catsclawarticle.htm, accessed in January 2008.

35. Einset, J.W.; A Practical Guide to Woody Plant Micropropagation; Jamaica Plain: Arnoldia, 1986.

36. Pereira, R. C. A.; Pinto, J. E. B. P.; Bertolluci, S. K. V.; Reis, E. S.; Correa, R. M.; Plant Cell Cult. Micropropag. 2007, 3, 69.

37. Pereira, R. C. A.; PhD Thesis, Universidade Federal de Lavras, Brazil, 2004.

38. Kohda, H.; Namera, A.; Koyama, A.; Yamasaki, K.; Tani, T.; Chem. Pharm. Bull. 1996, 44, 352.

39. Sandoval, M.; Okuhama, N. N.; Zhang, X. J.; Condezo, L. A.; Lao, J.; Angeles, F. M.; Musah, R. A.; Bobrowski, P.; Miller, M. J. S.; Phytomedicine 2002, 9, 325.

40. Pereira, R. C. A.; Pinto, J. E. B. P.; Bertolucci, S. K. V.; Castro, E. M.; Silva, F. G.; Cienc. Agrotec. 2006, 30, 637.

41. Pereira, R. C. A.; Douseau, S.; Castro, E. M.; Silva, F. G.; Bertolluci, S. K. V.; Acta Amazon. 2008, in the press.

Received: July 24, 2007 Web Release Date: July 25, 2008 